\title{
A nyelvtani nem hiányának következményei a magyar nyelvben
}

\section{1. rész}

Elekfi László emlékének

1. Bevezető gondolatok. A nyelvtani nem kategóriája a nyelvről való gondolkodás általunk ismert kezdetei óta foglalkoztatja a szakírókat. Ez nem is csoda, hiszen a nyelvtudomány bölcsőjét mind indoeurópai nyelveken és nyelvekben gondolkodók ringatták, s ezekben valóban fontos szerepet játszik a genusz.

Ezt a kategóriát a morfológia területén tartják számon mint a névszókat és névmásokat jellemző alapvető szóalaktani kategóriát, és már két és félezer évvel ezelőtt is felkeltette a nyelvről gondolkodók érdeklődését. Arisztotelésztől tudjuk,

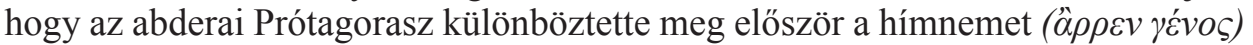

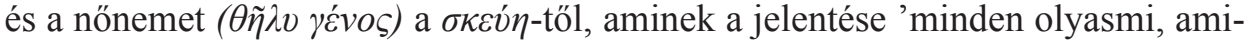
vel valaki vagy valami fel van szerelve' (,,alles, womit jmd. od. etwas ausgerüstet

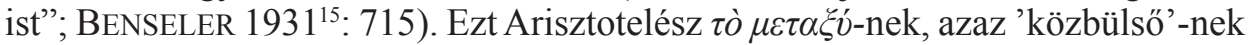
nevezte, ebből később a görögben ov̉déte $\rho o v$, latin tükörfordításban neutrum lett, $\mathrm{s}$ ez azt jelenti: 'egyik sem a kettő közül'. Fontos tény, hogy már a kezdetektől élesen megkülönböztették a természetes, biológiai nemet a nyelvtani nemtől a görögben is, ahol ugyan mindkettöre a $\gamma$ ćvo fönevet alkalmazták, a latinban azonban csak a nyelvtani nemet jelölte a genus, míg a természetes nemet a sexus kifejezés jelentette (LEUMANN-HOFMANN-SZANTYR 1965: 5).

A szókincs bizonyos elemeinek nemek szerinti osztályozása kisebb vagy nagyobb mértékben ma is jellemző az indoeurópai nyelvekre. Érthető tehát, hogy a modern európai nyelvtudomány kezdeti korszakától kezdve ismét foglalkoztatni kezdte a nyelvek kutatóit ennek a jelenségnek az eredete, funkciója. Kézenfekvőnek tünhetett, hogy a természetes nemek megkülönböztetésén alapult ez a grammatikai eszközrendszer, hiszen ahol nyelvtani nemről beszélhetünk, ott ez az élölények vonatkozásában valóban sokszor hozzájárul egy-egy főnév vagy névmás jelentéséhez. (Nem kis gondot okozva a modern genderelméletben, vö. pl. KÁLMÁN 2013; KISS 2014; PÉLI 2009; VASVÁRI 2014 stb.; l. továbbá a legújabb angol írásmódban az élőlényekre utaló személyes névmások nem-semlegesítését, pl. (s)he, vagy az 'elnök úr/asszony' minősített kifejezések helyett a semleges person és a rá visszautaló it névmás használatát is. Bár az angolban a 'nyelvtani nem'-et is a gender szó jelöli, mi ezt a kérdéskört végképp nem tekintjük a témánkhoz tartozónak.) Ugyanakkor a természetes nemre utalásban is rengeteg ellentmondásba ütközünk. Túl sok a kivétel, gyakori a hím- és nőnemü egyedekre egyaránt vonatkozó forma, azaz a communia, főként a többes számot jelölő és a függő esetủ szóalakok között; és hát mi indokolja, hogy egy asztal hím- vagy éppen nőnemü, különösen, ha ez a besorolás nyelvenként sem egyező, pl. lat. mensa, -aef; de ném. der Tisch).

A nyelvtani nem kialakulásáról szóló elméleteket magyarul igen részletesen ismertette már 1958-1959-ben FODOR ISTVÁN; a nyelvtani nemnek indoeurópai

Magyar Nyelv 115. 2019: 408-421. DOI: 10.18349/MagyarNyelv.2019.4.408 
nyelvekben megjelenő nyelvi formáit, a nyelvek egymásra hatásakor megfigyelhető változásait itthon többen is vizsgálták (STANITZ 1987; ÖRSI 2011). Legutóbb H. VARGA MÁRTA készített a biológiai és a nyelvtani nem nyelvi kifejezésének lehetőségeiről, a felismerhető szabályosságokról és a szabálytalanságokról több európai nyelvet átfogó rendszerező tanulmányt (2016).

A magyar nyelvből hiányzik minden grammatikalizálódott eszköz, amely ilyesféle szempont szerint osztályozná a megnevezési formákat, beleértve a természetes nemre utalást is. A szókincsnek a természetes nem megkülönböztetésére szolgáló lexikai elemeit - beleszámítva a királynö, királyné szavak utótagjait is nem tekinthetjük a nyelvtani nem grammatikai kategóriájába tartozónak, hiszen nem jár velük semmiféle nyelvtani változás a szövegkörnyezetükben. Azt, hogy esetenként más és más lehet például a megszólítás, köszönés módja a nők és a férfiak irányában, nem nyelvi, nyelvtani követelmények, hanem társadalmi elvárások: hagyományok vagy épp újítások szabályozzák. Arról viszont, hogy nyelvünknek ez a hiányossága nem valamiféle fogyatékosság, nem okozza a kifejezőképesség szegénységét, BUDENZ JÓZSEF (1881) kis vitairata óta nemigen olvashattunk. A nyelvi tankönyvek - a magyart idegen nyelvként tanítók is - legfeljebb leszögezik a nyelvtani nem hiányának tényét; pedig ez nemcsak azt eredményezi, hogy egyes szófajoknak másmilyenek a megjelenési formái, alkalmazási lehetőségei, mint a minket körülvevő népek nyelvében, de rányomja a bélyegét a szintagmaalkotási lehetőségekre, a mondatszerkezeteink másságára, végeredményben a nyelvi rendszerünk egészére és így a gondolkodásunkra is.

A köztudat a magyart a nehezen elsajátítható nyelvek között tartja számon, valószínüleg azért, mert nagyon sok szempontból eltér az újlatin, a germán és a szláv nyelvtanokból ismeretes elvektől. De azt hiszem, fordítva sem kisebbek a nehézségek. Emlékeztetnék itt a kötelező idegennyelv-oktatás gondjaira: a régi gimnazisták mumusára, a latinra, a sok évszázados német hatás hatástalanságára, a sok évtizedes orosztanítás „,eredményeire”, vagy arra, hogy mennyi fáradozásba és pénzbe kerül napjainkban, hogy a legalább középfokú idegennyelv-tudáshoz kötött diplomájukat végre átvehessék a két idegen nyelvet sok éven keresztül tanuló, felsőfokú tanulmányaikat egyébként sikeresen abszolváló, végzett hallgatók.

Talán könnyebb lenne leküzdeni a nyelvtanulási nehézségeinket, sőt még az anyanyelvi nevelésünknek is javára válhatna, ha a magyar nyelv sajátosságait a saját belső törvényszerüségei részletesebb feltárásával s nem a többnyire indoeurópai nyelvszemlélettel kialakított fogalmi skatulyákba való begyömöszölésével próbálnánk megérteni, illetve megértetni, mert ez utóbbi módszer könnyen Prokrusztész ágya lesz.

Bemutatni, hogy a nyelvtani nem hiányának milyen következményei is vannak a magyar nyelv egész rendszerére, olyan összevetés révén látjuk lehetségesnek, amelyhez fel kell használnunk a genuszos nyelvek párhuzamba állítható sajátságait is.

2. Miben mutatkozik meg a nyelvtani nem? Az indoeurópai nyelvekben a fönév inherens tulajdonságának tekintik a nyelvtani nem szerinti hovatartozást, ami a többi szófajra az egyeztetés által terjed ki aszerint, 
hogy milyen kapcsolatokban állhatnak a fönévvel. A mondatszerkesztés alapelvének megfelelően ezekben a nyelvekben a világ valós és elképzelt entitásait jelölő fönévvel egyeztetni kell minden olyan elemét a mondatnak, amely az adott fönévre, pontosabban annak denotátumára vonatkozik. Ennek megfelelően azokat a szófajokat érinti a genusz jelensége, amelyekkel a fönév predikatív vagy jelzős szókapcsolatokat alkothat, tehát elsősorban a mindkét pozícióra alkalmas n é v má s okra és a melléknévvel rokonságot mutató szófajokra terjed ki a nemek szerinti megkülönböztetés. Így figyelmet kell szentelni a s z á m n é v nek, az i g e n e v e k nek, sőt az i g é k ragozási rendszerének is, a segédszók közül pedig a n é ve lő k kapnak egészen különleges szerepet ebben a vonatkozásban.

A szintag mán belüli, ,nemben, számban és esetben kötelező” a laki e g y e z te té s mindig nagy hangsúlyt kap az indoeurópai nyelvek tanulása során. Kevesebb szó esik a szövegalkotás tanítása, gyakoroltatása közben arról, hogy a nemre utalásnak hatalmas kohéziós ereje van a mondategység hatá rá n tú 1 is. Pedig a névmások genusz szerinti megoszlásában elsősorban ez a fontos, hiszen a mutató névmás kivételével a többi fönévi névmás csak minimális mértékben vesz részt jelzős szerkezetek alkotásában, megkerülhetetlenek viszont az anaforikus kapcsolatok megteremtésében, nemcsak az összetett mondat, de a z egész szöveg koherenciájának biztosításában is.

A minimálisra csökkent morfológiájú angol nyelvben a nem, a gender kifejezése a mai nyelvállapotban épp az élőlényekre utaló személyes névmásokra korlátozódik, ezzel válik a legegyszerübbé a lehetséges antecedensek közül az aktuális egyes szám harmadik személyűnek az azonosítása. Mivel pedig az élettelen dolgok nemek szerinti megkülönböztetése a megszemélyesítések kivételével gyakorlatilag megszünt (kivételt képeznek a még mindig nőnemünek tekintett hajómegnevezések), az élőlényekre utaló egyes szám harmadik személyű személyes (és a ragozott alakjának is tekinthető birtokos, továbbá a belölük összetétellel alkotott visszaható) névmások megosztottsága hagyományosan és értelemszerủen a természetes (és általában eléggé nyilvánvaló) biológiai nemet tükrözi.

3. Élő vagy élettelen? A szókincs elemeinek osztályokba rendeződése - legalábbis az indoeurópai nyelvcsaládban - nagy valószínüséggel az élőlények és élettelen dolgok megkülönböztetésével indulhatott. A cselekvés végrehajtására képes élőlényekről szóló megnyilatkozásokban szükségessé válhatott a szenvedő, passzív fél (patiens) megkülönböztetése az aktív cselekvőtől (az agenstől), míg az élettelen dolgokra irányuló aktivitásnál ez magától értetődő. E mellett a kiindulási lehetőség mellett szól a semleges nem általánosan érvényes fő szabálya, amely minden olyan nyelvben jól demonstrálható, ahol az esetek morfológiailag jelöltek: a semleges nemü szavak alany- és tárgyesete következetesen megegyezik. Ennek az a magyarázata, hogy az élettelen, tehát nem-agens létezőket jelentő fónevek eredetileg nem is lehettek alanyai a cselekvésről referáló állításnak, mindig a patienst fejezték ki, ami az élőlényt jelentő szavaknál ezért akkuzatívuszi alakban rögzült. Később az életteleneket jelentő, és akkor még valószínűleg se nem hím-, se nem nőnemü szavak (neutrum) ,alanyként is fellépő elemei egyéb lehetőség híján az akkuzatívuszi alakot alkalmazták a nominatívusz kifejezésére is". (HAVAS 


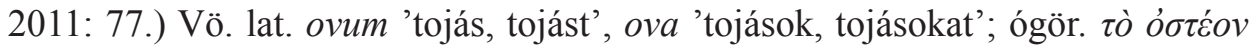
'csont, csontot', $\tau \grave{\alpha} \partial \sigma \tau \varepsilon \dot{\alpha} \alpha$ 'csontok, csontokat' ${ }^{1}$. A semleges nem kialakulásának és az élő-élettelen ellentétnek az összekapcsolását segíthették olyan szinkrón nyelvi tények, hogy például az orosz nyelvben ugyanez a ragozási szabály nemcsak a semlegesnemúként számon tartott főnevek esetében érvényesül, hanem az élettelen dolgot jelentő hímneműek paradigmájában is, még ha a nyelvtörténet más-más fejlődési ívet rajzol is a különböző indoeurópai paradigmák kialakulásáról. (Vö.: стол 'asztal, asztalt', столье 'asztalok, asztalokat'; de 'fiú' = мальчик, 'fiút' = мальчика; 'fiúk' = мальчики, 'fiúkat' = мальчиков.)

A sexus szerinti nyelvtani különbségtevés jelentősége kezdetben az élőlényt jelentő főnevek között is elhanyagolható lehetett, a szükséges információhoz a fónév lexikai jelentése elegendő tájékoztatásul szolgált, mint ahogy szolgál ma is a genusz nyelvtani kategóriáját nem ismerő nyelvekben is. A szójelentés hatását felerősíthette a szóvégek összecsengetése: a nőnemre gyakran jellemző $-a(\sim-e)$ melléknévi végződésnek lehet ez a magyarázata. A hangsúlytalan szóvégek kopása és a sokszor klitikumként is csatlakozó szóelemek találkozását kísérő hangtani változások a különböző nyelvekben persze jócskán felülírhatták az esetleg korábban meglevő hasonló hangzást is. A hímnem és nőnem átterjedését az élettelen dolgok neveire sokféleképpen és néha sehogy sem magyarázhatjuk (vö. H. VARGA 2016), de feltételezhetően hozzájárult a biológiai és a nyelvtani nem szétválásának folyamatához. Míg az utóbbi részben megmaradt egyfajta lehetőségnek a természetes nem megkülönböztetésére is ( $\mathrm{pl}$. a 'farkas' általában lupus, $-i, m$, de Romulusék felnevelöje lupa, -ae, f), egyre fontosabb elemmé vált a szövegkohézió nyelvi eszközkészletében annak ellenére, hogy a külön nyelvi fejlődés során rengeteg homonima és összeolvadás alakult ki a névszói paradigmákban. A latinban például a mássalhangzós és félhangzós tövü névszóragozásban (3. és 4. deklináció) a semlegesek említett nominatívuszi és akkuzatívuszi eseteit leszámítva egyáltalán nincs nem szerinti megkülönböztetés a függő esetalakokban. A magánhangzóra végződő tövek nagyjából megoszlanak ugyan: az 1. és az 5. deklináció - a- és - $e$ - tövü főneveinek többsége nőnemü, az -o- tövüek (2. deklináció) általában hím- vagy semlegesnemüek, de a függő esetekben itt is sok a homonímia. Ráadásul a kivételeket is be kell bifláznia a latinul tanulónak, mert a genus magán a fónév alakján nem feltétlenül látszik meg, azt mindig a szótő szerinti deklinációnak megfelelően kell ragozni, viszont a melléknevek és névmások egyeztetése már a fönévi nemhez is igazodik, de a saját tőtípusuknak megfelelő végződésekkel, 1. 'ókori földmüves' = agricola antiquus (fn 1. dekl., masc. $\rightarrow \mathrm{mn}$ : masc., 2. dekl.); 'jó talaj' humus bona (fn 2. decl. fem. $\rightarrow$ mn: fem., 1. decl.); 'új vírus' = virus novum (fn 2. dek1., neutr. $\rightarrow$ mn. neutr., 2. dek1.); 'rövid idö' tempus breve (fn. 3. decl., neutr. $\rightarrow$ mn neutr., 3. dek1.); 'jobb kéz' = manus dextra (fn 4. dekl., fem. $\rightarrow$ mn fem., 1. dekl.), 'ünnepnap' dies festus (fn 5. dekl., masc. $\rightarrow$ mn masc., 2. dekl.) stb. Ha a melléknév történetesen mássalhangzós vagy - $i$ - tövü, tehát a 3. deklinációba tartozik, ott a hím- és nőnemü névszók még a nominatívuszban is csak a néhány háromvégződésü melléknév esetében különböznek (pl.

${ }^{1}$ Az alapfokú nyelvoktatásból megismerhető nyelvi tények bemutatásakor eltekintek az ilyen nyelvkönyvek valamelyikére való állandó hivatkozástól. 
celer, celeris, celere 'gyors'), de a ragozásban csak a semlegesnemüek azonos nom. $=$ acc. végződései térnek el a többi nemtől.

Az élö-élettelen nyelvi szembeállítását és ezzel a nyelvtani nem kezdetleges megjelenését szokták látni olykor a magyarban is a ki? és $m i$ ? kérdő névmások következetes megkülönböztetése miatt. A magam részéről óvakodnék ettől a feltételezéstől több okból is.

Mai nyelvünkben a kérdő ki-t nem általában az élölények, csupán emberek azonosításának igénye esetén használjuk (beleértendő természetesen, ha ez a megszemélyesítés stilisztikai eszköze), de nem szerepelhet már a biológiai nemük szerint egyébként lexikailag megkülönböztetett, esetleg tulajdonnévvel megjelölt állatok iránti érdeklődésekben sem. Ha a gyerek sírva szalad hozzám, mert monokli van a szeme alatt, tudni akarom, $\mathrm{ki}$ bántotta, de ha fogak nyoma van a lábán, annak járunk utána, mi haraphatta meg. Ha a focista megsérül a pályán, a kérdés az, hogy k i rúgta meg; ha a tehenészt éri baleset az istállóban, nem azt kérdezem: „K i öklelte fel?”, csak azt: „Melyik bika (vagy tehén) volt az?”

Nyelvünkben azonban még a személy - nem-élólény grammatikai megkülönböztetése sem kötelező elöírás, mert a nyomatékviszonyok döntik el, hogy valamit mutató vagy személyes névmási elemmel említünk-e kötelező vonzatként egy anaforikus utalásban, pl.: Húzd alá a föneveket, és olvasd fel ö ket hangosan! - Húzd alá a föneveket, de csak a z ok at olvasd fel, amelyekben ly van! Ha nincs bennük ly, ne is törödj velük, azokkal a továbbiakban nem foglalkozunk! És persze a személyekre vonatkoztatott utalásban sincs semmi bántó, ha például egy fényképen mutatjuk, vagy egy távolabb álló személy felé intve mondjuk: Ez itt / Az ott a nagypapám. - Mindezek fényében érdekes viszont az a megszorítás, amit a számállapot-határozó használatában figyelhetünk meg. Míg a Hárm a n már megérkeztek mondat vitathatatlanul emberekről szól, nagy valószínüséggel a Há ro m már megérkezett mondatot fogjuk használni, ha várt csomagokról, kirándulókat szállító buszokról, sms-üzenetekről stb. beszélünk. Az osztályban azt kérdezem: Hány a n hiányoznak, de a rókák által meglátogatott csirkeólnál már azt: Hán y hiányzik?

Visszakanyarodva a ki névmáshoz: különösen a vonatkozó és határozatlan használatú egyedei a nyelvtörténet során korántsem mutatták a kérdésben ma megfigyelhető megkülönböztetést, vö. csak a Toldiban is idézett Ilosvay-sort: ,,és ki i a csizmáján viselt, s a rka n tyúj át ". A vonatkozó aki használatában pedig ugyan még sokakat ingerel, napjainkban mégis úgy tünik, feltartóztathatatlanul terjed a cégünk, aki...; a kormány, aki...; egyetemek, akik...; négy olyan megye, aki...; azok az országok, akik... stb. (Talán nem érdektelen azonban, hogy ezek a köztévéből, hivatásos beszélőktől, szóvivőktől származó példák mind e m b e r e k által képvise $1 \mathrm{t}$ és irányított intézményre utalnak.)

4. A nyelvtani nem megjelenése a szófaji rendszerben. A továbbiakban abból a tényből indulunk ki, hogy az indoeurópai nyelvekben minden fônévi lexéma beletartozik az adott nyelvben (esetleg nyelvjárásban) létező két vagy három nyelvtani nem valamelyikébe - némelyik a szövegbeli aktuális jelentésétől függően akár többe is. Milyen hatással van ez a szókincs többi elemére? 
Az nyilvánvaló, hogy a főnevekkel szintagmatikus kapcsolatba nem lépő szófajok - az elsődleges mondat- és kötőszók, módosító partikulák - eleve kívül maradtak a nemek szerinti osztályba tagozódáson. A szükségszerüen adverbiális szintaktikai pozícióba kerülő névszói és névmási eredetủ másodlagos elemei a szókincsnek - a határozószók és igekötők, valamint az ige bővítményeinek szemantikai viszonyát jelölő elöljárók, illetőleg névutók - pedig kikerülni látszanak ez alól a hatás alól. A tipikusan a d n o mi ná li s bővítményként szereplő szófajokra azonban az egyeztetési kötelezettség következtében sajátos a $1 \mathrm{k}$ a $1 \mathrm{maz}$ k o d ó ké p e s s ég vált jellemzővé: az etimológiailag azonos tövek a domináns fönévhez aktuálisan igazodó végződéseket vettek fel, ezáltal már lexémaként is többalakúvá váltak. Ez a többalakúság általában jellemző a főnevet determináló névszókra, igenevekre, névelőkre, valamint a névmásokra.

4.1. A név má s o k különleges állapotot mutatnak ebből a szempontból. Amint a fentiek alapján várható, genusz szerinti változékonyságot tapasztalunk minden olyan névmáson, amely jelzőként kerülhet kapcsolatba egy főnévvel, tehát a melléknévi jelentésárnyalatot is hordozó névmásokon. Ezek általában etimológiailag azonos névmási tövön, esetleg sajátos, névmási esetvégződéssel mutatják a kérdő és határozatlan típusoknál a semleges nem föszabályából eredő nominativus-accusativus egyezést (pl. lat. nom. quis - quid, acc. quem quid), ami az élö-élettelen általános szembeállítását tükrözi; csak a mu ta tó é s vo n a tkozó értelmü névmásokon érvényesül a nőnem megkülönböztetése is (is - ea -id, hic - haec-hoc, qui-quae - quod stb.).

A természetes nem kifejezési igényének elsődlegességével ütközni látszik, hogy a kizárólag fónévi értékben használható s z e m é ly e s é s bir to k o s névmások közül sem az 1., sem a 2. személyre utalók nem mutatnak genusz (vagyis egyben sexus) szerinti megoszlást: ismereteim szerint egy indoeurópai nyelvben sincs 'énfiú' vagy 'tenő' jelentése semelyik egyenes vagy függő esetalakjuknak sem. A beszédpartnerek eleven kommunikációs kapcsolata nyilván feleslegessé teszi ennek az információnak a nyelvi megformálását. Ezek a névmások jelzőt nem kaphatnak, viszont a predikatív és értelmezős szerkezetekb e n, valamint a mondategység határán túlmutató a naforikus utalás ok b a n a többalakú szófajok már e g y e z te tö d n e k a beszélőnek és partnerének a „normális” beszédhelyzetekben nyilvánvaló biológiai nemével is. (A névmások sokezer éves történetében nem nevezem ,normális"-nak a csupán néhány évtizede létrehozható e-mail- és egyéb online kommunikációs kapcsolatokat.) Figyelmet érdemel azonban, hogy a beszélőtől és a beszédpartnertől különböző - harmadik - személy(ek)re utalás mennyire van rokonságban az élő és élettelen környezetre egyaránt utaló többalakú mutató névmásokkal. Az ógörögben és a latinban is ezek használatosak harmadik személyü személyes névmás gyanánt. - A birtok os névmások genusz szerinti váltakozása pedig nem a birtokos, hanem a birtok nemére utal (vö. lat. amicus meus, ancilla mea; ném. meine Freundin; or. моё письмо, illetve чей - чья - чьё 'kié').

Az első, illetve második személyü névmással k or e fer e n s vis s z a h a tó

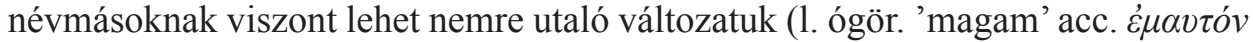

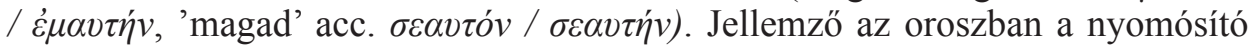


szerepü, (a magyar én magam típusú) értelmezőszerü szerkezetekben használatos сам-сама-само egyeztetődése, ellentétben a tényleges visszahatás esetén mindenkire egyaránt eleven patiensként utaló себя egyetlen alakjával. Ez a tény pedig alátámasztja azt a hipotézist, hogy a genusz kategóriája elsősorban a koherens szövegalkotásra szolgáló anafora eszközeként $\mathrm{v}$ álh a t o t t fontossá, ezért maradhatott meg még a modern angolban is az egyes szám harmadik személyủ személyes névmásoknál. És ezért nem tartom eretnek gondolatnak, hogy az indoeurópai genusz nem csupán a föneveknek inherens tulajdonsága, hanem a mára kialakult 3 . személyre utaló személyes névmásoké is, amelyek valóban helyettesítik a föneveket.

4.2. A melléknév a főnevekhez a legtöbb szállal, a legsokoldalúbb viszonyban kötődő szófaj. A főnévvel megnevezzük a világ dolgait, de a melléknevek jelölik meg azokat az érzékszervileg megtapasztalható külső, anyagi vagy gondolatilag kikövetkeztethető, esetleg csak elképzelt belső, szellemi tulajdonságokat, amelyek alapján a dolgokat egymástól megkülönböztetjük: szín, alak, méret, minőség, állapot, térbeli és időbeli meghatározottság (pl. szélső, új) stb. És mivel egyetlen észlelt vagy feltételezett tulajdonság sem létezik valamilyen hordozó nélkül, a melléknév akcidenciális jelentése mindig egy fónévvel - vagy azt helyettesítő névmással - jelölt szubsztanciára vonatkozik. Ha összefüggésük a mondatban fö mondanivalóként jelentkezik (vagyis a kérdéses minőséget állítjuk az adott szubsztanciáról), predikatív kapcsolatba kerül a két szó, amit a beszélő intonációval, szórenddel, kopulával, a nyelv eszközeiből adódó egyeztetéssel tud jelölni. Ha csupán a pontosabb kifejezésmód érdekében említünk egy olyan jellemzőt, ami akár predikáció is lehetne, de az aktuáli is közleményben csupán másodlagos, mellékes információ, jelzős szerkezetben determinálja a fönevet, de ebben az esetben is alapvető követelmény, hogy kiderüljön, melyik főnévhez melyik melléknév tartozik. Erre kiváló lehetőség a genuszt alkalmazó nyelvekben az egyeztetés, ami azonban korántsem jelentheti a végződések mechanikus ismétlődését. Erről fentebb a tőtípus és a nemek különbözősége kapcsán is volt már szó, s jól mutatják ezt mindazok a nyelvek, amelyekben még világosan megkülönböztethetők az egyes nemek és eltérő tövek bizonyos esetalakjai, mint a görög, a latin vagy a modern szláv nyelvek közül például az orosz. (Pl. ógör. $\delta \beta \alpha \sigma l \lambda \varepsilon \dot{s} \varsigma \mu \varepsilon^{\gamma} \gamma \widetilde{\alpha} \varsigma$ 'a nagy király', akk. $\tau \grave{\nu} v \beta \alpha \sigma i \lambda \dot{\varepsilon} \bar{\alpha} \mu \dot{\varepsilon} \gamma \check{\alpha} v$; lat. 'ua.' rex magnus, gen. regis magni; or. точное время 'pontos idö', gen. точного времени.)

Vannak fogódzók az ilyen nyelvet tanulók számára is: a tövek, végződések, képzők, bizonyos jelentéskörök jelezhetnek bizonyos szabályosságokat, de mindig marad jó sok kivétel. A szótárakban megadott alakokból többnyire ki lehet következtetni a tőtípust, a görög és a német szótárak feltüntetik a főnév nemét mutató névelőt is, a latin lexikológiai hagyományban a nominatívuszi és genitívuszi alak együttese mutatja, melyik deklináció szerint kell a fönevet ragozni, de hogy milyen alakban kapcsolódhatnak hozzá a melléknevek, a particípiumok, a névmások, azt a két esetalak után legalább $m, f, n$ formában rövidített genusz-jelzés alapján lehet csak bizonyosan tudni. Ezért az idegen nyelv felől indulónak „be 
kell vágnia" a lexémával együtt azt is, hogy milyen nemü, és ezt nem könnyíti meg sem az, ha a névelőt, sem az, ha egy rövidítést kell hozzátanulnia. Mert hiába van meg az anyanyelvében is ez a kategória, semmi sem garantálja, hogy az adott főnév neme a két nyelvben egyezik. Ezért szokták a magyarul tanulók örömmel nyugtázni, hogy erre legalább nem kell figyelniük.

Némileg könnyebb a helyzet az orosz nyelvvel, ahol a fönevek túlnyomó többségében már a lexéma alapalakjának számító alanyeset is mutatja a nembeli hovatartozást ( $-a,-я$ nőnemü, $-o,-e,-м я$ mindig semleges, a kemény mássalhangzóra végződőek hímneműek). Itt a melléknévi egyeztetés legtöbbször hangtanilag is igazodik a főnévi szóvéghez, a jelzői használatban még rá is dupláz azzal, hogy agglutinálódott az eredetileg artikulusi funkciót betöltő ji/ja/je mutató névmás. Ezzel a jelzős szerkezet egységét emeli ki, ami azért is fontos, mert az oroszban az egyeztetett jelző állhat a fönév előtt, de a főnév után is, és nincs artikulus, ami a szókapcsolatot összefogná. Így kialakultak a csak melléknevekre jellemző végző-

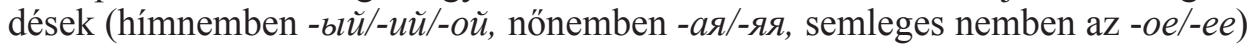
és velük a saját ragozásuk is. A melléknévnek ez a teljes alakja a jelzőre nézve kötelező, a predikatív egyeztetésben többnyire elegendő a rövid alak, amely persze szintén egyezik az alannyal nemcsak számban (és ragozhatatlanként az egyetlen esetében), hanem genusz szerint is.

4.3. A z ig e n e vek szinkrón szempontból nézve az igei jelentés valamilyen névszói értékü használatát jelentik. Elvben minden igéből képezhetünk igeneveket, képzőik a legproduktívabb szóalkotó elemek. Amikor a beszélő fónévi vagy melléknévi értékben - alanyi, tárgyi, határozói funkcióra, illetve jelzőként igenevet alkalmaz, azt úgy rendeli alá egy valódi állítmánynak, hogy megőrzi az ige denotatív jelentésével együtt annak aspektuális tartalmát (relatív, az aktuális állítmányhoz viszonyított időre utalását), nem veszíti el az igenem szerinti (tranzitív/aktív/mediális/passzív) szerkezetszervező képességét, tehát vonzza az annak megfelelő bővítményeket is. Elvesznek viszont az ige állítmányi pozíciójában nélkülözhetetlen tulajdonságok: az igei, konjugációs végződések ugyanis a tempus (vagyis az eseményidőre vonatkoztatás) és a modus (a beszélőnek az esemény tényszerüségéhez való viszonyulása) mellett a mindenkori alany személyét és számát mutatták. Mindazokban az esetekben, amikor egy particípium mégis állítmányi szerepben fordul elö, az összetett igealakhoz ma már segédigére van szüksége. „Cserébe” részesül az új, névszói szerepkörhöz szükséges alaki tulajdonságokból: a fónévként szolgáló igenevek bizonyos fönévi toldalékokat vehetnek fel. Például a latin gerundium a 2. deklináció függő esetalakjait, miközben nincs nominatívusza; az infinitívuszok eredetileg egy latívuszi/datívuszi irányultságú névszói toldalékkal alakultak ki (vö. MORAVCSIK 1972); a magyar főnévi igenév ezen kívül a névszói személyjelöléssel utal a saját -nak/-nek ragos ,,alanyára”, bizonyára nem függetlenül a magyar birtoklás-mondatok szerkezetétől.

A genuszos nyelvekben a főnévi igenevet semleges nemünek tekintik, fönévi igeneves fejü szerkezetekre semleges nemü névmással lehet visszautalni. A melléknévi értékü igenevek - általában ezeket nevezzük particípiumoknak - a melléknévre jellemző alaktani ka- 
tegóriákat vesznek fel, így alakulnak párhuzamosan deklinálhatóvá a mondatnak azzal a fónévi tagjával, amelyhez szintagmatagként kapcsolódnak.

Hangsúlyozzuk: így mindenképpen egy szinkrónnak tekintett nyelvállapot beszélőjének a szempontjából tekintünk az igenevekre, még ha az ógörög vagy a klasszikus latin szempontjából ezt mához képest évezredekkel korábban beszélték is. Nehéz lenne kétségbe vonni ugyanis a történeti nyelvtipológia azon tételét, hogy a particípiumok eredetileg predikátumok voltak, s hogy „, deverbális nomen « képlet »de-verbális « momentuma történetileg csak abban az esetben tartható, ha verbumon nem a mai értelemben vett teljes paradigmájú szófajt értünk, hanem egy olyat, amelyet mindenekelött predikatív használata különböztet meg a többi szófajtól, sajátos személyragozása pedig vagy nincsen, vagy még kialakulóban van" (HAVAS 2011: 163, 165-172).

4.4. A z igé kn él általában nem merül fel a genusz kifejezésének igénye, amíg egyszerü igeidőkkel van dolgunk, hiszen az igének mindig egy nominatívusszal megnevezett alanyra kell vonatkoznia, elegendő tehát a beszélöre vagy partnerére irányuló utalások megkülönböztetése a bárki/bármi egyéb harmadik személyütől a személyragozással. Ez az ősi személyes névmások hozzátapadásával mehetett végbe a predikátumként álló szavakon. A magyar alanyi ragozás kijelentő módjában a jelen idejű 3 . személyre vonatkozó állítmányt épp az eredeti ragtalanság megörzése különbözteti meg az összes többi igealaktól - a folyton változó főnévi alanyok nyilván nem agglutinálódhattak -, míg a toldalékait elvesztő angolban ez az egyetlen megmaradt személyrag. Az igeragozási rendszerek bővülése azonban szükségszerủen vezetett az összetettebb igealakok létrejöttéhez. Jól példázza a folyamatot a latin, amelyben a folyamatos igealakok még egyszerü toldalékolással fejezik ki az idő- és módváltást ('lát': Sg.1., ind. ps. vide-o, praet. vide-ba-m, fut. vide- $b-o$, coni. ps. vide- $a-m)$ és a szenvedő jelentést is (vide-o-r) stb., a perfecta actio-ban ez az igető megváltozásán túl a ragozott létige (kopula?) hozzátapadásával érhető el (praet. vid-eram, fut. vid-ero, coni. ps. vid-erim). (Innen ered az igeragozás latin neve is: con-iugatio 'összekapcsolás'.) A szenvedő alakokhoz azonban már összetett igealakokat hoztak létre, amelyben a p a r t i c i pium perfectum passivi adja az igei jelentés fogalmi tartalmát, passzív igenemét, befejezett aspektusát, miközben számban, es etben és nemben névszóként egyeztet az a lannyal, az eseményidőhöz viszonyító tempust pedig és az alany személyével való egyeztetést különálló létige (kopula) biztosítja (visus/a/um sum). Vagy egy ógörög példa: a futurum perfectum aktív alakját a genusz és szám (és persze eset) szerint egyeztetendő participium perfecti és a létige személyt és számot mutató futurumával alkották meg: $\pi \varepsilon \pi \alpha \downarrow \delta \varepsilon v \kappa-\omega ́ \varsigma /-$

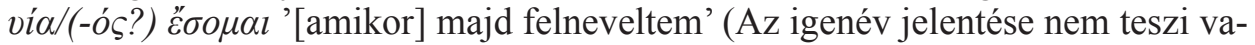
lószínúvé, hogy semleges nemủ alannyal kellett valaha is egyeztetni.)

Az indoeurópai nyelvek igeragozási rendszereiben mindenütt megtaláljuk a particípiumok segítségével alkotott formákat, ez pedig azt jelenti, hogy az igealak megválasztásában sem hagyható figyelmen kívül a nyelvtani nem szerepe. Különösen érdekes ebből a szempontból az orosz nyelv, amelyben ma egyetlen múlt idő használatos, ennek az egyeztetése azonban - rendhagyónak tünő módon - az alany személyére nem, csupán a nemére és számára utal. Észre kell vennünk, hogy 
a $-л /-л а /-л о$ és a többes $-л и$ végződések kísértetiesen hasonlítanak az állítmányi melléknevek rövid alakjára. A magyarázat a fentebb elmondottakban rejlik. A mai orosz nyelv egyszerü igealaknak látszó múlt idejű formája valójában egy - $l$ képzős participium állítmányi alakja, amely eredetileg egy összetett múlt idő, a perfectum állítmánykiegészítői tagja volt. A perfectum a szorb nyelv kivételével a keleti és nyugati szláv nyelvekből kiszorította az ősi egyszerü praeteritum imperfektum és aorisztosz alakokat, és a múlt idő kifejezésének általános formájává lett. Az egyes szláv nyelvekben még további átalakulásokon ment át az igenév képzője is, és a byti kopula is, amely az oroszban teljesen eltünt - talán nem függetlenül az oroszban általános névszói állítmány jelenségétől. (L. H. TóTH 2011: 140-144.)

A particípiumoknak az igeragozásban való megjelenésével függ össze, de a 4.3. pontban elmondottakhoz is tartozik, hogy az infinitivus esetében, amely alapalakjában valóban 'nem ragozható', szintén kialakulhattak particípiumokkal létesített összetett formák. Ezért a latinban például a nagyon is gyakori a c c . c . in f. és nom.c.inf. szerkezetekben ügyelni kell az összetett fönévi igenevek nembeli, számbeli és esetbeli egyeztetésére is.

4.5. A s zámneveket szokták a melléknevek egyik alosztályaként kezelni, de ennél több figyelmet érdemelnek. - A s o r s zámneve k valóban jól belesimulnak ebbe a felosztásba: egyébként sem mennyiséget jelölnek, hanem egy rendezett halmazon belül elfoglalt helyzetet, tehát jelentésükben is hasonlítanak az utolsó, középsö, szélsö, bal stb. melléknevekhez. Következésképpen funkciójukban és annak megfelelő alaki tulajdonságaikban is egyeznek velük, ami azt jelenti, hogy melléknévi végződéseik vannak, tehát az adott nyelvre jellemző módon mutatják az általuk jelölt pozíciót elfoglaló dolog nevének genuszát (tertius3). - A törtszámneveket ugyancsak funkciójuk alapján kezelik melléknévként vagy főnévként - ez utóbbi esetben saját genuszértékkel ruházva fel őket, pl. a németben das Drittel vagy az oroszban nőnemü четверть. - A tős zám n evek közül csak a legkisebb értéküek tükrözik a számlált dolgok

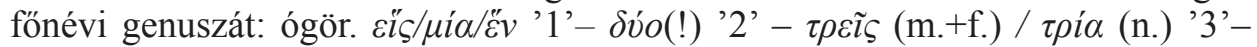
$\tau \dot{\varepsilon} \tau \tau \alpha \rho \varepsilon \varsigma(\mathrm{m} .+\mathrm{f}$.) / $\tau \dot{\varepsilon} \tau \tau \alpha \rho \alpha$ (n.) '4'. A latinban az unus/una/unum és a duo (m.+n.) / duae (f.) mellett a tres/tria viszont a semlegest választja külön a közös hím- és nőnemtől. A latinban 200-900 között a kerek százasok, a görögben pedig a kerek ezresek szintén háromnemü melléknevekként egyeztetődnek, természetesen többes számú formával: ducenti/ducentae/ducenta, illetve $\chi^{i} \lambda \iota$ lol $\chi \chi_{i} \lambda \imath \alpha l / \chi i \lambda l \alpha$, stb. Az oroszban csak az один/одна/одно '1', továbbá a (hajdani duális számra még „,emlékező"?) два/две '2' és оба/обе 'mindkettő', valamint a полтора/полторы 'másfél' egyeztetődik a főnév nemével, ez utóbbi három a nőnemet különbözteti meg a hím- és semleges nemtől. A németben csupán az eins számnév veszi fel a hozzá tartozó fơnév nemének megfelelő melléknévi formát (ein/eine/ein). A tőszámnevek túlnyomó többsége azonban az indoeurópai nyelvekben ragozhatatlan, nemcsak nemek, hanem eset szerint is, és ennek véleményem szerint két fó oka lehet. A tőszámnév jelentésénél fogva a mellékneveknél és a sorszámneveknél is jóval alkalmasabb arra, hogy elvonatkoztassuk bármely számlálható dologtól, hiszen kétszer kettö mindig négy - ebben valószínüleg szerepe van a több ezer éves matematikai gondolkodásnak. Ugyanakkor a fónévvel alkotott szókapcsolatának 
jelentésbeli alapja is eltér a melléknevekétől: míg azok a főnévvel jelölt entitások halmazán belül valamilyen megkülönböztető tulajdonsággal választanak ki egy aktuális részhalmazt (amely egytagú is lehet), a tőszámnév mindig egynemü dolgok halmazán belül különít el azonos tulajdonságokkal rendelkező egyed(ek)et, tehát nem minősítéssel determinál, hanem partitív jelentése van a szókapcsolatnak. Ezt a tartalmat teszi explicitté például mai állapotában az orosz nyelv, amelyben az 1-nél nagyobb tőszámnevekkel létesített szintagmákban a fönév egyes vagy többes birtokos esetbe kerül (méghaez történetileg nem is egyforma fejlődés eredménye, amit persze az átlagbeszélő nem is tud), $\mathrm{s}$ a szerkezet alaptagjaként a birtokszó szerepében álló számnév ragozódik a mondatbeli funkciónak megfelelő eset szerint. (Pl. через две недели 'két hét múlva', ahol a számnév a birtokos esetben álló fónév nőneméhez igazodik, de eset szerint nem vele egyezik, hanem az elöljárószó által megkívánt tárgyesetben áll.)

4.6. A más odlag os s zó faj ok sajátosságait is befolyásolhatja a nyelvtani nem, ha azok a szövegbe épülő fönév aktuális viszonyait segítenek kifejezni, és a vele egyeztetéses kapcsolatban álló szavakból alakultak ki. Ezek között a legfontosabb a né velö, amit célszerübb ebben az összefüggésben a r tikulu s nak neveznünk, hiszen például a határozott artikulusok számos nyelvben, így a bolgárban, a románban és a svédben sem előzik meg a főnevet, hanem a szóvégre tapadnak.

Az artikulus, amely jelentésében a fónév határozottsági fokára utal - ismertségére a beszédpartnerek számára, vagy épp egy tetszés szerinti új példány bevezetésére -, kialakulásával más fontos feladatokat is vesz magára. Jelezhető vele a szófaji jelleg fönévire váltása ( $A$ z els ő már megjött; the poor 'a szegények'); meg mutatja a fön év nemét (fr. un collègue 'kolléga', une collègue 'kolléganő'); nemmel is felruházza a genusztól eredetileg független szófajt váltó elemeket is (pl. ném. das Leben); összetartja a fónévi szószerkezeteket, de le is választja nem odatartozó elemeket (a magas, szöke férfi $\neq$ magas a szöke férfi;

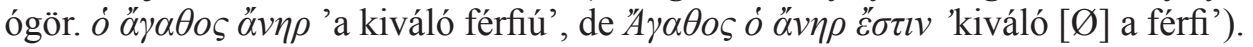

A határozott artikulusok közös jellemzője, hogy a kijelölő funkciójú mutató névmásból alakultak ki, a deiktikus jelentés elhalványulásával egyidejüleg végbemenő hangsúlytalanná válás révén. Emiatt figyelhető meg rajtuk többnyire az alakjuk redukciója, továbbá esetenként összetapadásuk a főnévvel. A szóvégek kopásával párhuzamosan nőtt a grammatikai szerepük a genusz, illetőleg az eset jelölésében. Talán elég csak arra utalnunk, milyen hatással van a német jelzős szerkezetben a határozott névelő a melléknévi ragozásra. - A ha tározatlan artikulus nem feltétlenül párhuzamos a határozottal: a bolgár nyelvben nincs is, a románban ritka, és ha megjelenik, bizonytalan az artikulusi értéke, mondhatni alakulóban van, a németben és angolban viszont gyakori. Bármelyik indoeurópai nyelvben találkozunk is vele, az 'egy' jelentésü határozott számnévi jelzőből értékelődött át, és akárcsak számnévi őse, a határozatlan artikulus is egyeztető ragozással igazodik az általa determinált fönév neméhez is.

A főnév szintaktikai funkcióját kifejező esetrendszert kiegészítő, egyes modern nyelvekben pedig már helyettesítő viszonyszók, a z e 1 ö $1 \mathrm{j}$ á ró $\mathrm{k}$, vagyis prepozíciók az ige vonzataiként mentesek lehetnének a genusz szerinti váltakozásoktól, mégis számolnunk kell esetükben is a főnév nemétől is függő használattal. Alkal- 
manként ugyanis a gyakori együttállás következményeképpen összenőhet a prepozíció és a névelö, mint pl. az olaszban: $a+i l>a l$ vagy in $+l a>n e l l a$, vagy a német in + das $>$ ins, in + dem $>$ im esetében. Ez eredményezheti új szófaji kategória kialakulását is, mint amilyen az olasz vagy a francia nyelv r é s z e lő né ve lőj e. A németben a határozatlan névelőből fejlődött ki olyan t a g a d ó v i s z o n y s z ó, amely ugyancsak tükrözi a tagadott fönév nyelvtani nemét: kein/keine/kein.

5. A nyelvtani nem hiányának hatása a magyar szófajokra. Lehet, hogy furcsának tünik egy rendszerben annak a hatását keresni, ami nincs is benne, de ha olyan rendszereket vetünk össze, amelyeknek egyikében megvan egy bizonyos jelenség, a másikból hiányzik, kézenfekvő, hogy mindkét rendszerben számba vegyük a kérdéses kategória által érintett pontokat, és azt is megvizsgáljuk, hogy a nyilvánvaló különbség milyen eltérésekhez vezethetett a más-más tulajdonságú elemekből felépülő rendszerek müködésében.

Mivel sem az élö/élettelen, sem a férfi/nő jelentés nem mutatkozik meg semmilyen hangzásbeli eltérésben a fő n e vek alakját tekintve, ennek a jelentésmozzanatnak ragozásbeli vonzata sincs. A mi főneveink mondatbeli grammatikai alakváltozatait - az agglutináló tendencián és a szabályosan mindig első szótagra eső hangsúlyon kívül - csak a hangrend és illeszkedés törvénye befolyásolja. Mai nyelvállapotunkban erre még a nyelvtörténet során végbement változások rakódnak rá, amelyek a többalakú tövek váltakozásáért meg a toldalékok előhangzós alakváltozatainak ,logikátlanságáért” okolhatók (elsősorban a tővégi magánhangzók lekopása és a kétnyíltszótagos tendencia). Mindez persze nem teszi egyszerübbé a magyar fónevek ragozásának rendszerbe foglalását, hiszen minden egyes szónak megvan a saját története. Bizonyára ez is oka a magyar nyelv sokat emlegetett nehézségének. Erre nézve elég utalnunk PAPP FERENC (1975) és ELEKFI LÁSZLÓ (1994) munkáira. Magától értetődik, hogy ha nem kell a főnévhez igazodni nemek szerint, akkor a főnévvel szószerkezeti kapcsolatba lépő egyéb szófajokon sem jelentkezik semmi ilyesféle megoszlás. Ezért aztán n in c s e n e k lexikai alakjukban is két- vagy háromvégződésü névmásaink, mellékneveink, számneveink, igeneveink és viszonyszavaink, sem ezeknek valamilyen - nemek szerint is változó speciális ragozásuk.

A lexémának ez az alaki függetlensége a vele szemantikailag bármily szoros kapcsolatban levő főnévtől nagyobb önállóságot jelent az alkalmazásuk lehetőségeiben is. Sokkal könnyebben főnevesülhetnek, s nem csupán absztrahálódás révén; ez a genuszos nyelvekben sem jelent sok problémát, általában a semleges nem felvételét kívánja meg. A jelzős szerkezetek redukciója azonban már nem történhet meg legalább az elmaradó fönév nemére való utalás nélkül. (Az angol a genuszjelölés hiányában a one névmást teszi ki, ha másképp nem tud elkerülni egy felesleges szóismétlést.) Mi ilyenkor a kieső főnévi alaptag szintaktikai viszonyjelölő toldalékát egyszerü hangrendi egyeztetéssel áttesszük a determinánsra, ami ezzel felemelkedik a főnév pozíciójába. Ami azt is jelenti, hogy akcidenciális jelentésủ, melléknévi tulajdonságú szavaink gyakorlatilag minden olyan funkcióban felhasználhatók a mondatban, 
mint a fönevek, ehhez felvehetik mindazokat a viszonyjelölő grammatikai eszközöket, amelyeket a valódi fönevek vennének fel, miközben m e gőrzik a melléknévi kategóriájukra jellemző alaki sajátosságokat is : jelentésüknek megfelelően fokozhatók, és megmaradnak saját bővítményeik is. Természetesen az ő toldalékolásukra nézve is érvényesek az olyan fonológiai törvényszerüségek és nyelvtörténeti változások, amelyek a fönévragozást is befolyásolják. (A pontosság kedvéért említsük meg, hogy a kis melléknév és a két számnév csak jelzőként használható, minden más szerepben a kicsi és kettő alakváltozatok fordulnak elő.)

Mindebből az is következik, hogy melléknévi elemeinknek akkor sem kell kivetkőzniük a saját természetükből, amikor nem egy főnevet minősítenek, hanem közvetlenül kapcsolódnak az igéhez vagy egy igenévhez. Ilyenkor „saját jogon” vesznek fel minden olyan szintaktikai viszonyjelölő eszközt, azaz h a tá r o z ó r a g o t, amelynek a segítségével a hely-, idő-, eszköz- stb. jelentéseken túl a mód-, mérték- és állapotféle határozók szerepére is alkalmassá válnak: Nagyon s z ép $a z$ írásod $\leftrightarrow$ Nagyon szépen írsz; Itt a korábbinál sokkal gyor sabb a Duna fo lyás a $\leftrightarrow$ Az itt a korábbinál sokkal gyors abban folyó Duna könnyen elsodorhatja az úszót; Úgy szereti, ha a kávé édes $\leftrightarrow$ Édes en szereti a kávét.

A melléknévi jellegü szófajok mássága visszahat az egész szófaji rendszerre és az alaktanra. Egyfelől kialakul az indoeurópai nyelvekhez képest koherensebb kategóriaként a névszók os ztálya, mivel a magyar melléknév és a vele sok rokonságot mutató számnevek mondatbeli funkciói és azoknak megfelelő ragozhatósága gyakorlatilag megegyezik a fỏnévével. Legfeljebb olyan jelentésmegoszlással találkozunk, mint hogy az előhangzók megszilárdulásával - $n$ határozóragunk alakváltozatai alsó nyelvállású magánhangzóval a melléknévi természetủ mód- és állapotféle határozói jelentésre specializálódtak (beleértve a számnevekkel kifejezhetó számállapot-határozót is) - igaz, nem kizárólagos érvényesüléssel (vö. fiatalon, nagyon, vakon stb.). A számneveknek a melléknevek mellé - nem pedig közéjük - sorolását is indokolja a csak rajtuk elöforduló -szor/-szer/-ször toldalék, amelynek szintaktikai viszonyt jelölő tartalma, valamint eleven (100\%-os) produktivitása a számhatározói funkcióban szintén a határozóragokra jellemző. Másfelől e zér t h i á n y z i k nyelvtanainkból hagyományosan az adverbiumképzés fejezete, és ezért tartalmaz a magyar h a tá r o z ó s zó k állománya kizárólag olyan lexikai elemeket, amelyek a jelentés specializálódása következtében mind elemszilárdulással váltak a szókészletnek új tulajdonságokat mutató tagjaivá. Az ilyenek pedig már legfeljebb csak jelentésváltozással bonthatók alkotóelemeikre. Szemléltetésül egy homonim példa a határozószóvá merevedett, illetve csupán aktuálisan ragozott névmási helyhatározó különbözőségére: Er re gyere, itt nincs sár! (Me r re? 'a mutatott irányba', névmási határozószó); Itt egy söralátét, e r re tedd a poharat! ( $M i-r e$ ? 'a kapott söralátétre', ragos névmással kifejezett helyhatározó).

És végül: ezért van nekünk a fönévi és melléknévi igenevek mellett kizárólag adverbális bővítményként használható határozó i igenevünk, amely (nem a kopulával, hanem) a létige mellett állva (pl. zárva van) ezért nem „ha- 
tározói állítmány” vagy „állítmányi határozó”, hanem „határozó é s állítmány”, mégpedig a Milyen állapotban van? kérdésre felelő állapothatáro zó, akárcsak a növés-ben van, tudatá-nál van, ébr-en van stb. szerkezetek határozóragos névszói szófajú vonzatai. Kétségtelenül valamennyien a létigével együtt felelnek a Mit állitok? kérdésre, de ettől még nem lesznek egy grammatikai összetett állítmány névszói része. Az igei rész sem úgy viselkedik, mint nyelvünkben az - esetenként szintén állapotjelentésü, de nem határozói alakú - ragtalan névszó mellett a jelen időben zéró fokú kopula (pl. A gyerek kanyarós). Fókuszba helyezésüket az általuk adott információ fontossága indokolja, ezzel a ré má na k válnak elemévé, ami azonban egy egészen másfajta elv szerint épül fel, mint az alany-állítmány szintagmatikus kapcsolata. Nemcsak nyelvoktatásunkban, egész nyelvtanírói hagyományunkban okoz sok haszontalan vitát, félremagyarázást és félreértést, hogy a különböző szempontú elemzésekkel feltárt eredményeket, valós tényeket elnagyolt definíciókkal, tisztázatlan terminológiával, a szempontok keverésével összebékítve próbáljuk egyetlen közös keretbe kényszeríteni ahelyett, hogy mindegyiket a maguk helyén kezelnénk. (Az alanyés állítmányfogalom tisztázatlanságáról 1. pl. BERRÁR 1977: 80-81; ELEKFI 1957, 1986: 18-24; M. KORCHMÁROS 2018.)

(Folytatjuk.)

M. KORCHMÁROS VALÉRIA Szegedi Tudományegyetem 